\title{
Physical and chemical characteristics of goldenberry (Physalis peruviana) grown in Lam Dong province, Vietnam
}

\author{
*Thuy, N.M., Phuong, N.P., Suong, C.T.D. and Tai, N.V. \\ Department of Food Technology, College of Agriculture, Can Tho University, Can Tho city, Vietnam
}

\begin{abstract}
Article history:
Received: 26 February 2020

Received in revised form: 19

March 2020

Accepted: 22 March 2020

Available Online: 12 April 2020
\end{abstract}

Keywords:

Goldenberry,

Chemico-physical

characteristics,

Storage,

Physalis peruviana

Quality changes

\section{DOI:}

https://doi.org/10.26656/fr.2017.4(4).085

\begin{abstract}
This work was carried out to determine the physical and chemical properties of goldenberry fruit (Physalis peruviana L.) grown in Lam Ha and Don Duong of Lam Dong province in Viet Nam. The shelf-life and quality of fruits during storage time at ambient temperature $\left(28 \pm 2^{\circ} \mathrm{C}\right)$ were also analysed. The analysis results recorded that most of the physical properties of the fruit grown in the two locations (Lam Ha and Don Duong of Lam Dong province, Viet Nam) yielded no significant differences, except the volume, density, hardness and colour of the fruit. The fruit grown in Lam Ha has a lighter colour and yellow intensity (higher $\mathrm{a}^{*}$ and $\mathrm{C}$ value) than the ones grown in Don Duong, while the fruits are grown in Don Duong are darker (lower $\mathrm{L}^{*}$ and higher $\mathrm{H}_{\mathrm{o}}$ ). In addition to its attractive properties in terms of colour, aroma and taste, they also contain moderate levels of vitamins ( $\mathrm{C}$ and $\mathrm{A}$ ), antioxidants (polyphenols), minerals (especially high content of phosphorus) and fibre. Fruit grown in Don Duong had a higher sweetness than those grown in Lam Ha (the ratio of sugar and acid was 2.7 times more). The concentration of bioactive compounds in the goldenberry fruits grown in Lam Ha and Don Duong were almost similar. The shelf-life of goldenberries up to 20 to 22 days at the ambient temperature of about $28 \pm 2^{\circ} \mathrm{C}$ and $75-80 \% \mathrm{RH}$ but the quality and sensory characteristics of goldenberry raw materials were declined.
\end{abstract}

\section{Introduction}

Physalis peruviana, a plant belonging to the genus Physalis of the nightshade family Solanaceae, is native to Peru (Morton, 1987) with many English names as Cape gooseberry, Goldenberry, and Physalis. The cultivation of Physalis originated from South America and then has been cultivated in England and South Africa. Nowadays, $P$. peruviana is grown/grown wild all over the world, almost in subtropical and tropical countries. As an exotic fruit, P. peruviana becomes an economical crop for export and development in breeding and cultivation in many countries, including Viet Nam. The ripen fresh yellow berries colour ranged from yellow to orange and the fruit was protected and cover by calyx during developing and ripening (Figure 1).

The goldenberry fruit has been informed as a rich source of nutrients (vitamins, minerals, antioxidants), all of them together would give these fruits medicinal properties as described by Puente et al. (2011). With moderate fibre content, phenolic compounds and low levels of calories (Ozturk et al., 2017), goldenberries can be consumed as a healthy snack which are powerful elements of human health. The combination of all nutrients and bioactive compounds in fruits will make it become high-value products. Besides that, the goldenberry has a sweet and sour flavour, they can become a popular ingredient in confectionery processing (various cake and candy), jam, sauce and salads. According to USDA nutrient analysis, $100 \mathrm{~g}$ goldenberry is low in energy $(53 \mathrm{kcal})$ and contains moderate levels of vitamin $\mathrm{C}$, thiamin and niacin, polyphenols and carotenoids. The content of polyphenols and vitamin $\mathrm{C}$ varied by cultivar, harvesting time and ripening stage (Bravo et al., 2015).

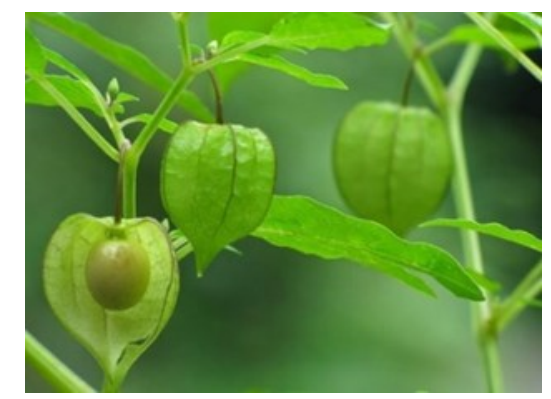

Figure 1. The fruit has a small round shape like tomatoes, the outside is wrapped in a thin shell 
In Vietnam, South American variety goldenberries had begun to plant with large areas in Lam Dong province. The fruit is mostly used in fresh form. Nowadays, these fruits are also used more in the diet of Vietnamese people because of the health benefits that they bring. So far, no information about fruit quality grown in Viet Nam has been published. Besides, goldenberry is a highly perishable fruit that was a limitation on its commercialization. Therefore, analysing the chemical and physical characteristics and determining the storage time of fruits as necessary and fulfil the requirement of industry for postharvest technology of these fruits. This article will be first informed the nutritional components and quality changes of goldenberries during storage. This work will assist the scientists to better design a specific machine for harvesting and post-harvesting operation of these fruits in Viet Nam.

\section{Materials and methods}

\subsection{Sample collection}

This study was the first report on the chemical and physical characteristics of goldenberry in Viet Nam. In this study, the American Southern variety goldenberry was used as the material which was harvested from two locations (Tan Ha, Lam Ha and Lac Lam, Don Duong districts) of Lam Dong province, Vietnam. Fruits were grown during the season from July to December 2019. The fruit was harvested randomly. It was harvested carefully by hand and cleaned properly to remove all the foreign matters such as dust, dirt etc. Maximum efforts were made to select the fruit uniform in size, good in quality and free from injury or disease. The harvested fruit was analysed and stored in well ventilated wooden boxes at Department of Food Technology, Can Tho University, Vietnam. The storage temperature was kept at $28 \pm 2^{\circ} \mathrm{C}$

\subsection{Determination of physical characteristics}

The mass of fruit ( $\mathrm{g}$ ) was measured by using a digital balance with the sensitivity of $0.01 \mathrm{~g}$.

Length (L) and diameter (D) (mm) of goldenberry fruit were measured by using a digital calliper (accuracy of $0.01 \mathrm{~mm}$ ).

The geometric mean diameter $D g(\mathrm{~mm})$ was calculated from L and D using equation 1 (Mohsenin, 1986):

$$
\mathrm{Dg}=\left(\mathrm{LD}^{2}\right)^{1 / 3}
$$

The sphericity, Sp (\%) was determined using equation 2 (Mohsenin, 1986).

$$
S_{p}=100\left(D_{g} / L\right)
$$

The surface area and aspect ratio of the fruit were calculated as following equation 3 and 4 .

$$
\begin{aligned}
& S=\pi D_{g}^{2} \\
& R_{a}=D / L
\end{aligned}
$$

Where $\mathrm{S}$ is surface area $\left(\mathrm{mm}^{2}\right)$ and $\mathrm{R}_{\mathrm{a}}$ is an aspect ratio

The volume of fruit $(\mathrm{V})$ defined as the ratio of the mass of a sample to the solid volume accordingly occupied was determined by the liquid displacement method. The amount of displaced toluene $\left(\mathrm{C}_{7} \mathrm{H}_{8}\right)$ was recorded from the graduated scale of the measuring cylinder (Akbolat et al., 2008).

The bulk density is the ratio of the mass of fruit to its total volume and was determined with a weight per hectolitre tester, which was calibrated in $\mathrm{kg} . \mathrm{m}^{-3}$.

The fruit hardness was measured by NEWTRY test stand + hard fruit firmness penetrometer sclerometer fruit hardness Tester. The firmness of golden berries was measured with GY-3, diameter $8 \mathrm{~mm}$, press depth of test head $10 \mathrm{~mm}$.

The skin colour of goldenberries was measured by using Colorimeter (Japan) with fifty measurements were taken. $L^{*}, a^{*}$ and $b^{*}$ values were recorded and then these values were used to calculate Chroma (C) (equation 5).

$$
C=\sqrt{\left(a^{*}\right)^{2}+\left(b^{*}\right)^{2}}
$$

Hue angle $(\mathrm{H})$ value is the angle between the $a^{*}$ and $b^{*}$ axes (equation 6), indicating the colour saturation of the subject.

$$
H=\tan ^{-1}\left(\frac{b^{*}}{a^{*}}\right)
$$

Chroma and Hue angle were used for describing visual colour appearance (Bernalte et al., 2003).

\subsection{Determination of chemical characteristics}

The titratable acidity values were determined as $\%$ citric acid.

The total soluble solid content was measured using a refractometer and is referred to as the ${ }^{\circ}$ Brix.

The total sugar content was determined according to the method of McCseady (1971) and Dubois et al. (1956).

The total polyphenols were determined by the FolinCiocalteu (Olssen et al., 2006). Thus, the results were expressed in milligrams of gallic acid equivalent/100 g of sample.

The vitamin $\mathrm{C}$ content was determined by the 
titration method with iodine (Tran et al., 2004). Vitamin $\mathrm{C}$ content in the sample was calculated using equation 7.

$$
\operatorname{Vitamin} C(m g \%)=\frac{(a-b) \times 0.088 \times 100}{10} \times \frac{100}{m}
$$

Where $a$ is the volume of $0.001 \mathrm{~N} \mathrm{KIO}_{3} / \mathrm{KI}$ solution used for vitamin $\mathrm{C}$ extract $(\mathrm{mL}) ; b$ is the volume of 0.001 $\mathrm{N} \mathrm{KIO}_{3} / \mathrm{KI}$ solution used for control sample; 100 is the volume of volumetric flask $(\mathrm{mL}) ; 0.088$ is the weight of ascorbic acid corresponds to $1 \mathrm{~mL}$ of $0.001 \mathrm{~N} \mathrm{KIO}_{3} / \mathrm{KI}$ solution (mg); and $m$ is the weight of sample (g).

The $\beta$-carotene content was determined according to the method of Fikselová et al. (2008). The concentration of carotenes expressed as $\beta$-carotene was calculated using equation 8 .

$$
\beta \text { - carotene content }\left(\frac{\mu g}{g}\right)=\frac{A \times d \times V}{E_{1 c m}^{1 \%} \times W}
$$

Where $\mathrm{A}$ is the absorbance; $\mathrm{d}$ is dilution $(\mathrm{g} / \mathrm{mL}) ; E_{1 \mathrm{~cm}}^{1 \%}$ is the absorption coefficient of $\beta$-carotene in petroleum ether (2592); $w$ is the weight of sample $(\mathrm{g}) ; V$ is total volume of extract $(\mathrm{mL})$. Multiply by 100 to give the carotene content in $\mu \mathrm{g} / 100 \mathrm{~g}$.

The chemical composition of goldenberries fruit such as protein, moisture, crude fibre and fat determined by using standard methods (AOAC, 2005).

Total calories of the fruit were calculated by the formula as follows: total calories $(\mathrm{kcal})=$ fat $(\mathrm{g}) \times 9$ $(\mathrm{kcal} / \mathrm{g})+$ protein $(\mathrm{g}) \times 4(\mathrm{kcal} / \mathrm{g})+$ total carbohydrate (g) x 4 (kcal/g) (Thompson and Manore, 2017).

The determinations of calcium and phosphorus were carried out by flame photometry, followed the procedure of Arunkumar et al. (2015), using FP6410 Flame Photometer.

The weight loss: Initial $200 \mathrm{~g}$ fruit (in a transparent plastic box) was weighed with HL Electronic Balance, which has accuracy $0.001 \mathrm{~g}$. Fruits stored for 20-22 days at ambient temperature $\left(28 \pm 2^{\circ} \mathrm{C}\right)$ were weighed every 2 days. The results were converted into percentages with the equation: $\% \mathrm{WL}=\left[\left(\mathrm{W}_{i}-\mathrm{W}_{f}\right) / \mathrm{W}_{i}\right](100)$, where $\% \mathrm{WL}=$ percentage weight loss, $\mathrm{W}_{i}$ is initial fruit weight and plastic box in $\mathrm{g}, \mathrm{W}_{f}$ is final fruit weight and plastic box in $\mathrm{g}$ at the indicated time.

\subsection{Statistical analysis}

Data analyses were carried out using STATGRAPHICS Centurion XV (U.S.A.). Values were expressed as percentage and mean $\pm \mathrm{SD}$. The significance/ non-significance of results was determined using oneway ANOVA and Duncan test.

\section{Results and discussion}

The quality of the material resources has a great influence on the quality of the products being manufactured. Therefore, the selection of materials is extremely important. Fruit quality can be determined by physical and chemical properties and storage capacity.

\subsection{Physical properties of goldenberry}

Similar to other fruits, goldenberry fruit size and shape is the most important quality parameters. Determining the physical properties of the fruit can well support the post-harvest system designing including sorting, handling, packaging, storage and processing of fruit products (Table 1). The fruit grown in Lam Ha weights 4.87 to $7.30 \mathrm{~g}$ (mean value of $6.55 \mathrm{~g}$ ), a diameter of about 20.58 to $25.95 \mathrm{~mm}$ (the mean value of 23.57 $\mathrm{mm}$ ) and a length of 18.56 to $20.99 \mathrm{~mm}$ (mean value $19.97 \mathrm{~mm}$ ), smaller than a fruit grown in Don Duong with a mass of 5.59-8.03 g (mean value of $6.95 \mathrm{~g}$ ), diameter 21.56 to $24.98 \mathrm{~mm}$ (mean value of $23.07 \mathrm{~mm}$ ) and a length of 19.07 to $21,13 \mathrm{~mm}$ (mean value of 20.33 $\mathrm{mm}$ ). The diameter of berries can vary between 1.0 and $2.50 \mathrm{~cm}$ (Puente et al., 2011). According to many authors, the South American goldenberry variety weight may vary from 4 to $10 \mathrm{~g}$ (Ramadan, 2011; Puente et al., 2011; Ozdemir et al., 2016). The fruit is grown in Lac Lam, Don Duong have larger weight but smaller volume than those grown in Tan Ha, Lam Ha resulted show greater density value.

The geometric mean diameter of fruit and vegetables is one of the important physical properties for grading the samples size. The geometric mean diameter of goldenberry in this study varied from 19.88-24.18 and 20.66 to $23.48 \mathrm{~mm}$ for fruits grown in Lam Ha and Don Duong, with the mean values of 22.30 and $22.11 \mathrm{~mm}$, respectively. It was observed that there is no significant difference in sphericity between goldenberry berries grown in two locations, this may be due to their similar shape and size.

It was observed that there is no significant difference in sphericity between goldenberry berries grown in two locations, this may be due to their similar shape and size. The sphericity of goldenberry in this study varied from 107.13 to $111.66 \%$ and 108.32 to $113.20 \%$ for fruits grown in Lam Ha and Don Duong, with the mean values of 111.55 and $108.71 \%$, respectively. These values of goldenberries were higher than that of goldenberry sphericity reported by Yildiz et al. (2015), just around 91.5 to $107.6 \%$.

The surface area is an indication of the way the fruit will behave on oscillating surfaces during storage and processing. The mean surface area of goldenberry fruit 
Table 1. Physical properties of golden berry

\begin{tabular}{cccc}
\hline Physical properties & Number of replications & Tan Ha, Lam Ha & Lac Lam, Don Duong \\
\hline Length $(\mathrm{mm})$ & 100 & $19.97 \pm 1.56$ & $20.33 \pm 1.40$ \\
Diameter $(\mathrm{mm})$ & 100 & $23.57 \pm 2.36$ & $23.07 \pm 2.12$ \\
Geometric mean diameter $(\mathrm{mm})$ & 100 & $22.30 \pm 2.07$ & $22.11 \pm 1.79$ \\
Sphericity $(\%)$ & 100 & $111.55 \pm 1.81$ & $108.71 \pm 3.78$ \\
Surface area $\left(\mathrm{mm}^{2}\right)$ & 100 & $1573.44 \pm 289.19$ & $1544.29 \pm 249.16$ \\
Mass of fruit $(\mathrm{g})$ & 100 & $6.55 \pm 1.59$ & $6.95 \pm 1.49$ \\
Aspect ratio & 100 & $1.18 \pm 0.03$ & $1.13 \pm 0.06$ \\
Fruit volume $\left(\mathrm{cm}^{3}\right)$ & 100 & $5.01 \pm 1.27$ & $4.31 \pm 1.04$ \\
Fruit density $\left(\mathrm{kg}^{3} \mathrm{~m}^{-3}\right)$ & 100 & $1,311.86 \pm 57.07$ & $1,618.56 \pm 147.62$ \\
Fruit hardness $(\mathrm{N})$ & 100 & $7.84 \pm 2.67$ & $6.55 \pm 1.89$ \\
$\mathrm{~L}^{*}$ & 50 & $71.06 \pm 7.78$ & $62.59 \pm 2.13$ \\
$\mathrm{a}^{*}$ & 50 & $25.69 \pm 2.12$ & $16.29 \pm 0.86$ \\
$\mathrm{~b}^{*}$ & 50 & $62.48 \pm 2.34$ & $57.26 \pm 0.72$ \\
$\mathrm{C}^{\mathrm{H}}$ & 50 & $67.57 \pm 2.87$ & $59.54 \pm 0.89$ \\
\hline
\end{tabular}

Values are expressed as the mean \pm standard deviation. $\mathrm{L}^{*}$ : lightness, $\mathrm{a}^{*}$ : the red/green opponent colours, with green at negative $a^{*}$ values and red at positive $a^{*}$ values. $b^{*}$ : the yellow/blue opponent colours, with blue at negative $b^{*}$ values and yellow at positive $b^{*}$ values.

grown at Lam Ha was $1573.44 \mathrm{~mm}^{2}$ with a minimum value of $1242.02 \mathrm{~mm}^{2}$ and maximum value of 1836.57 $\mathrm{mm}^{2}$. Similar data were found in fruit grown at Don Duong, a minimum value of $1340.61 \mathrm{~mm}^{2}$ and maximum value of $1731.73 \mathrm{~mm}^{2}$ with the mean of $1544.29 \mathrm{~mm}^{2}$.

The similar aspect ratio of goldenberry fruit grown in Lam Ha or Don Duong was observed, these values in between 1.18 and 1.13, respectively. With the high aspect ratio, related the ratio of fruit diameter to length, it may be understood that the fresh goldenberry fruit will rather roll (Celik et al., 2007). Almost the obtained results from this study are higher to those reported by Yildiz et al. (2015).

Table 1 also presented the values for the firmness, this parameter reflects the integrity of the pericarp tissue, wherein the value obtained is 7.84 and $6.55 \mathrm{~N}$ for fruit grown in Lam Ha and Don Duong, respectively. Y1ld1z et al. (2015) presented that the average skin hardness of the goldenberry fruit in their study was $8.01 \mathrm{~N}$, it is quite similar to our obtained results. However, Trinchero et al. (1999) found that the firmness of the physalis berries in their study was $3.42 \pm 0.32 \mathrm{~N}$, this value obtained somewhat lower than that referenced by the authors, even when compared to our results. These differences may be due to the maturity of the berries fruit collected, the climatic and soil conditions of the area where the berries are grown.

Although there is no big difference between fruits grown in two localities in Lam Dong province, however, when taking measurements with a large number of fruits, the results showed that fruits grown in Lac Lam, Don
Duong show some characteristics better than those grown in Tan Ha, Lam Ha. Perhaps due to the annual temperature in Don Duong about $24^{\circ} \mathrm{C}$, a little higher than Lam Ha (only about $21^{\circ} \mathrm{C}$ ), so somewhat improved the quality of crop products.

The colour parameters in terms of $L^{*}, a^{*}, b^{*}, C$ and $H$ of goldenberries are also indicated in Table 1. Chroma $(C)$ is the strength or intensity of a colour. Hue $(H)$ is the name of a colour family and value $(L)$ is lightness or darkness of a colour. The $L^{*}$ value of fruits grown in Lam Ha, Tan Ha in the range of 69.67 to 72.87 (the mean value of 71.06), $a^{*}$ value in the range of 24.42 to 27.33 (mean value of 25.69 ), $\mathrm{b}^{*}$ value in the range of 61.69 to 65.17 (mean value of 62.48). The mean values of the $\mathrm{C}$ and $\mathrm{H}_{\mathrm{o}}$ for goldenberry were found to be 67.57 and 67.67 , respectively. The $L^{*}, a^{*}, b^{*}$ and $C$ values of fruits grown in Don Duong are lower than those grown in Lam Ha, however, the value of Hue angle $(\mathrm{H})$ is higher (as mentioned in Table 1). Based on the results of colour measurement and overall observations, it was found that the fruit grown in Tan Ha - Lam Ha had higher yellow intensity, brighter than the fruit grown in Lac Lam - Don Duong (Figure 2).

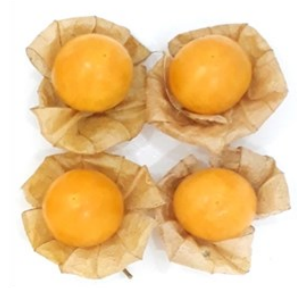

(a)

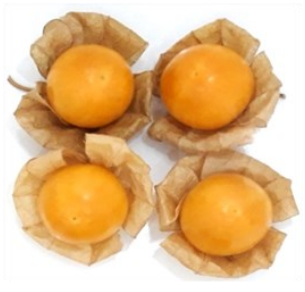

(b)
Figure 2. The South America variety goldenberries are grown in Lam Dong, Viet Nam. (a) Fruits are grown in Tan Ha, Lam Ha and (b) Fruit are grown in LacLam, Don Duong 
Valdenegro et al. (2012) reported L*, a*, b*, C and $\mathrm{H}$ values for goldenberries fruit were 69.56, 17.12, $60.78,63.15$ and 74.26 , respectively. These values are roughly in the middle of the fruit ranges grown in the two locations we studied, showing that the colour of the fruits in their study is almost the same as that of the fruit grown in Viet Nam. However, these colour values of fruit samples are higher than the corresponding values of $L^{*}$ (36.81), a* (16.71) and $b^{*}$ (37.47) reported by Vasquez-Parra et al. (2013) and Nawirska-Olszańska et al. (2017) with $\mathrm{L}^{*}, \mathrm{a}^{*}$ and $\mathrm{b}^{*}$ were $43.28 \pm 1.21$, $6.98 \pm 0.09$ and $29.77 \pm 0.94$, respectively.

\subsection{Some chemical characteristics of goldenberries fruit}

As indicated in Table 2, almost chemical parameters were not significantly $(\mathrm{p}<0.05)$ difference in goldenberries grown in two locations in Lam Dong, Viet Nam, except titratable acidity, sugar content and moisture content.

The titratable acidity is an important parameter in predicting the taste of the fruit. This may be important during the assessment of fruit quality. The average titratable acidity of goldenberries was found to be $0.79 \pm 0.14$ and $0.29 \pm 0.03 \%$ citric acid for fruit grown in Lam Ha and Don Duong, respectively. The analysis results showed that the goldenberries grown in Tan Ha had more sour taste than that of Don Duong, the acid content was shown to be 2.5 times greater. The mean titratable acidity value of fruit grown in Lam Ha was similar to the range of 0.78 to $1.83 \%$ reported for goldenberries by different researchers in their study (Ersoy and Bagci, 2011; Sharoba and Ramadan, 2011), but the acid content of fruits grown in Don Duong was much lower. Our obtained results were lower than the values reported in goldenberries fruit by Yildiz et al. (2015), the mean titratable acidity of goldenberries was $1.26 \%$ citric acid. The soluble solids content is a good indicator of the sugar content of fruit and presumably of sweetness. The total soluble solids and sugar content of goldenberry fruit grown in two locations showed no significant differences, the value obtained around 13.92 to $13.96^{\circ}$ Brix and 7.61 to $7.97 \%$, respectively. However, the titratable acidity (\%) (such as citric acid) of the fruits grown in Don Duong is lower than that in Lam Ha, resulting in a higher sugar/acid ratio, and the sweetness of fruits grown in Don Duong is much higher than Lam Ha. Rodrigues et al. (2009) reported the total sugars content is up to $8.9 \%$, including $6.4 \%$ reducing sugars. The lower results of the total sugar content of goldenberry were reported by Yild1z et al. (2015), they are $63.90 \mathrm{~g} / \mathrm{kg}$ which was composed $31.99 \mathrm{~g} / \mathrm{kg}$ reducing sugar. The higher soluble solid content of goldenberry fruit was observed by Sharoba and Ramadan (2011) and Nawirska-Olszańska et al. (2017), they reported that goldenberry fruit contains $16.40 \%$ water-soluble dry matter and the dry matter content reaches $10.4-17.24 \%$, of which $15 \%$ are soluble substances. Osorio and Roldan (2003) and Carrasco and Zelada (2008) found carbohydrate values as $11.00 \%$ and $17.30 \%$, respectively.

As mentioned by Hakkinen et al. (1999), the goldenberry is rich in phenolic compounds with the main phenolic compound is quercetin, myricetin and kaempferol (Hakkinen et al., 1999). The total phenolic content of goldenberries fruit grown in Lam Ha and Don Duong in our study were found to be $59.40 \pm 8.26$ to

Table 2. Some chemical characteristics (per $100 \mathrm{~g}$ ) of goldenberries fruit at different growing locations

\begin{tabular}{lccc}
\hline \multicolumn{1}{c}{ Parameters } & Number of replications & Tan Ha, Lam Ha & Lac Lam, Don Duong \\
\hline Titratable acidity (g) (as citric acid) & 50 & $0.79 \pm 0.14$ & $0.29 \pm 0.03$ \\
Vitamin C content (mg) & 50 & $46.31 \pm 4.47$ & $46.86 \pm 2.58$ \\
B-carotene content (mg) & 50 & $1.58 \pm 0.38$ & $1.63 \pm 0.08$ \\
Total phenolic content (mg GAE) & 50 & $59.40 \pm 8.26$ & $60.53 \pm 7.76$ \\
Moisture content (g) & 50 & $83.10 \pm 0.52$ & $77.82 \pm 1.24$ \\
Total soluble solid content ( ${ }^{\circ}$ Brix) & 50 & $13.92 \pm 0.49$ & $13.96 \pm 0.74$ \\
Total carbohydrate (g) & 50 & $7.61 \pm 0.20$ & $7.79 \pm 0.40$ \\
Protein (g) & 50 & $1.79 \pm 0.08$ & $1.68 \pm 0.07$ \\
Lipid (g) & 50 & $0.82 \pm 0.09$ & $0.71 \pm 0.06$ \\
Total calories (kcal) & 50 & $44.95 \pm 1.66$ & $42.54 \pm 1.71$ \\
Sugar/acid ratio & 50 & $15.56 \pm 2.82$ & $41.14 \pm 4.14$ \\
Calcium (mg) & 50 & $12.48 \pm 0.35$ & $13.12 \pm 0.82$ \\
Phosphorus (mg) & 50 & $56.33 \pm 4.84$ & $53.67 \pm 4.41$ \\
Fibre (g) & 50 & $4.23 \pm 0.20$ & $4.31 \pm 0.27$ \\
\hline
\end{tabular}

Values are expressed as the mean \pm standard deviation. $\mathrm{L}^{*}$ : lightness, $\mathrm{a}^{*}$ : the red/green opponent colours, with green at negative $a^{*}$ values and red at positive $a^{*}$ values. $b^{*}$ : the yellow/blue opponent colours, with blue at negative $b^{*}$ values and yellow at positive $b^{*}$ values. 
$60.53 \pm 7.76 \mathrm{mg} \mathrm{GAE} / 100 \mathrm{~g}$, respectively, greater than the value obtained from fruit samples $(29.5 \pm 0.9 \mathrm{mg}$ GAE/100 g) that reported by Nawirska-Olszańska et al. (2017). However, these values were lower than the results obtained (145.22 mg GAE/100 g) from Yildı et al. (2015).

Ramadan (2011) and Ozturk et al. (2017) reported that vitamin $\mathrm{C}$ content of cape gooseberry/goldenberry samples varies from 38 to $43 \mathrm{mg} / 100 \mathrm{~g}$ and 31.40 to $35.10 \mathrm{mg} / 100 \mathrm{~g}$, respectively. All these results were a little lower than the results achieved in our study (46.31 to $46.86 \mathrm{mg} \%$ ). Ascorbic acid amounts were similar to given $43.0 \mathrm{mg} / 100 \mathrm{~g}$ in the study done by NRC (National Research Council, 1989).

The b-carotene amounts of goldenberry sample grown in two locations in Lam Dong, Viet Nam has shown variability between 1.58 to $1.63 \mathrm{mg} / 100 \mathrm{~g}$. Ramadan (2011) also reported that goldenberry contained $1.6 \mathrm{mg} \%$ of carotenes with $70 \%$ of trans- $\beta$ carotene included. Ozturk et al. (2017) reported the carotene contents of the goldenberry between 1.98-2.30 $\mathrm{mg} / 100 \mathrm{~g}$. The other results were found by Ombwara et al. (2004) and Sharoba and Ramadan (2011) with the content varied 1.61 and $2.38 \mathrm{mg} / 100 \mathrm{~g}$, respectively. In ripe fruits, (all-E)- $\beta$-carotene (55\%) and several carotenoid fatty acid esters, especially lutein esters esterified with myristic and palmitic acid as monoesters or diesters (Etzbach et al., 2017).

The other chemical compositions such as protein, fat, total energy and fibre of goldenberries grown in Lam Dong province of Viet Nam were determined. These fruits contained lower values of protein, lipid and energy value, there were 1.68 to $1.79 \%, 0.71$ to $0.82 \%$ and 42.54 to $44.95 \mathrm{kcal}$, respectively. The majority of their calories come from sugar content in fruits. The greater values obtained by Rodrigues et al. (2009), they found that the content of $1.85 \%$ and $3.16 \%$ with the relatively high energy value $(88.72 \mathrm{kcal})$. The result of protein in our study was similar to those reported by Sharoba and Ramadan (2011), they proposed goldenberry fruit contain $0.84 \%$ protein. Goldenberries grown at different locations in Lam Dong, Viet Nam contained moderate fibre content, about 4.23 to $4.31 \mathrm{~g} / 100 \mathrm{~g}$. These collected data from our study were slightly higher than the published data from Ozturk et al. (2017) with the research on goldenberry grown in Turkey, the fibre content from 3.18 to $4.1 \%$ were found. The chemical characteristics of goldenberry fruit in our research were found to be different in comparison with some goldenberry studies in other countries. This could be explained by the fact that ecological factors, different climate and growing conditions affect the composition of goldenberries.

With antioxidants, vitamins and minerals (calcium and phosphorus) and fibre, so that consuming the goldenberry fruit can be beneficial to the human body.

\subsection{Changes in quality during storage of goldenberries}

\subsubsection{Colour}

The goldenberries vary from bright yellow to dark orange after 20 to 22 days of storage (Figure 3). It was found that the $L^{*}$ value of fruit falls sharply during storage and decreased from 69.67 to 41.67 within 20 days of storage. Instead, the $a^{*}$ value tended to increase from 24.42 to 39.67 . The $b^{*}$ value of fruit decreased slightly from 65.17 to fruits and 58.87. A sharp decline in the $L$ value and a tendency to slightly decrease the $b$ value of fruit indicated that the fruit is entering a recession.

The symptoms of disease in fruits are soft rot with a collapse and water soaking of parenchyma tissues, followed by the appearance of grey masses of conidia after 22 days of storage at ambient temperature (Figure $4)$.

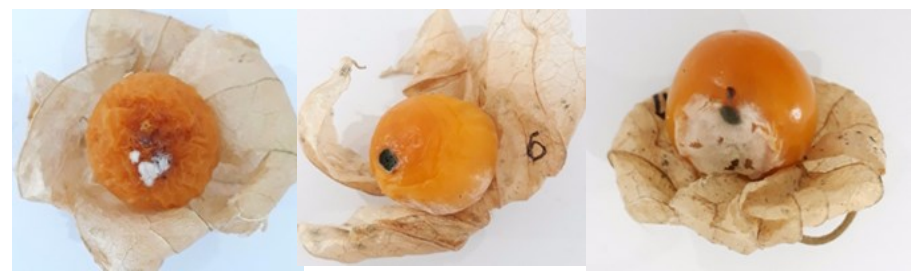

Figure 4. The goldenberries fruit senescence and decay simulation after 20 days of storage at ambient temperature $\left(28 \pm 2^{\circ} \mathrm{C}\right)$

\subsubsection{Weight loss}

Fresh produce continues to lose water after harvest. The goldenberries contained 77.82 to 83.10 per cent of water, their percentage of weight loss was about $18.71 \%$ after 20 days of storage at ambient temperature $\left(28 \pm 2^{\circ} \mathrm{C}\right)$ (Figure 5). The weight loss of fruit is mainly associated

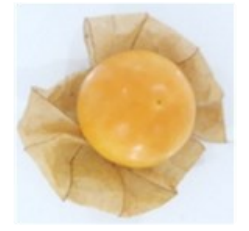

After harvesting

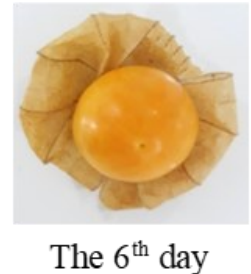

The $6^{\text {th }}$ day

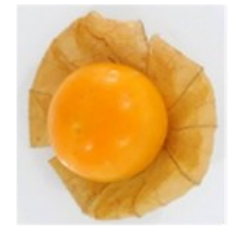

The $12^{\text {th }}$ day

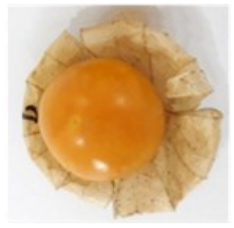

The $18^{\text {th }}$ day

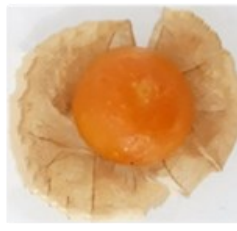

The $20^{\text {th }}$ day

Figure 3. The colour change of post-harvest goldenberries (during 20 days of storage at ambient temperature $28 \pm 2^{\circ} \mathrm{C}$ ) 
with moisture evaporation through the skin and respiration of fruit. The thin skin of goldenberries fruits made them susceptible to rapid loss of water resulted in shrivelling and damage. Increasing in normal physiological changes can be caused by high temperature, low atmospheric humidity and physical injury. Based on the obtained results, the percentage weight loss over time is represented by the polynomial regression model $\left(\mathrm{y}=0.022 \mathrm{x}^{2}+0.589 \mathrm{x}-0.555\right)$ with a high coefficient of determination $\left(\mathrm{R}^{2}=0.97\right)$, allowing the use of this model to predict the weight loss of the fruit at any time of storage.

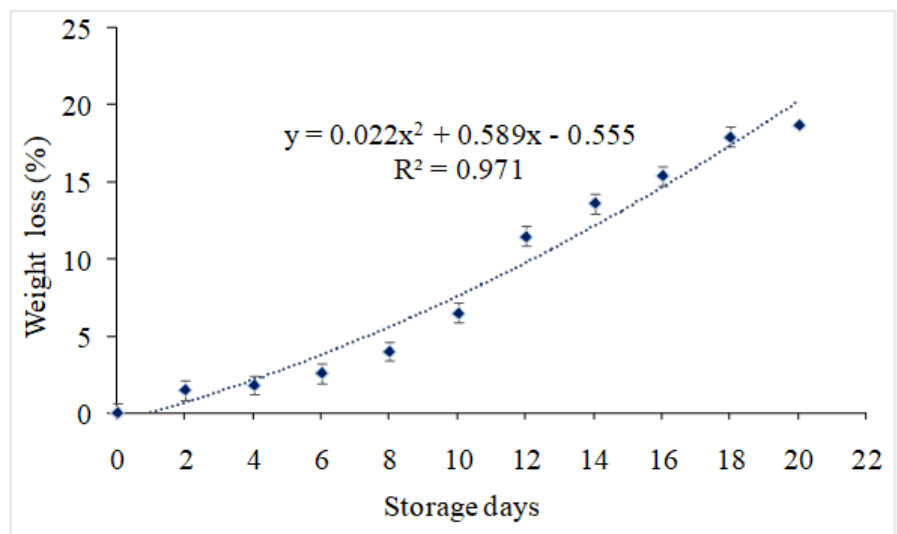

Figure 5. The average weight loss (\%) of goldenberries during 22 days of storage at ambient temperature $\left(28 \pm 2^{\circ} \mathrm{C}\right)$

\subsection{Chemical properties changes}

The chemical properties also changed significantly during this time.

Organic acids are decreased during fruit ripening because most of the acid is used in the process of respiration. The obtained results showed that the percentage loss of acid content in fruit was about $52.82 \%$ after 22 days of storage (from the average initial content of $0.75 \pm 0.01 \%$, the lowest value remained in the fruit was $0.35 \pm 0.02 \%$ ). The decrease of acidity of goldenberry fruit was also reported (Valdenegro et al., 2012), there were $53.67 \%$ and $41.38 \%$ respectively with yellow and orange stage fruit.

Total phenols had the same trend with oscillations during storage, but the losses of polyphenols were less, the average value of the fruit on the first day of storage was $63.88 \pm 0.65 \mathrm{mg} \mathrm{GAE} / 100 \mathrm{~g}$ and the lowest value was found $(43.64 \pm 0.37 \mathrm{mg} \mathrm{GAE} / 100 \mathrm{~g})$ in goldenberries stored at $28^{\circ} \mathrm{C}$ at the end of the storage period (22 days), the average percentage loss was about $31.97 \%$.

The ascorbic acid content is very labile and it easy rapidly declines during the postharvest stage. This behaviour has been reported for almost vegetables. However, it may still have a beneficial effect on human health. The analysis results showed that ascorbic acid content of goldenberry fruit decreased after 22 days of storage at ambient temperature. The mean initial ascorbic acid content of $45.17 \pm 0.86 \mathrm{mg} / 100 \mathrm{~g}$ remained unchanged for the first 8 days, then decreased slightly until the $14^{\text {th }}$ day and continued to decrease more until the $22^{\text {nd }}$ day, the remaining content was $26.25 \mathrm{mg} / 100 \mathrm{~g}$, so that the percentage of losses of ascorbic acid after 22 days of storage is estimated at $41.89 \%$. Significant decrease in ascorbic acid in fruit during storage may be attributed to its degradation into dehydro-ascorbic acid, furfural and hydroxy furfural (Panda, 2013). Valdenegro et al. (2012) also announced a decrease in vitamin $\mathrm{C}$ content by about $53.67 \%$ and $41.38 \%$ at the yellow and orange stage, respectively after 14 days storage at controlled temperature $\left(20^{\circ} \mathrm{C}\right)$.

The content of beta-carotene changed significantly during storage. The initial values decreased from $1.71 \pm 0.03$ to $0.27 \pm 0.02 \mathrm{mg} / 100 \mathrm{~g}$ after 22 days of storage, the estimated percentage loss about $81.23 \%$. Based on these results, it is suggested that goldenberries must be kept at a low temperature to preserve their nutrient content.

\section{Conclusion}

The physical characteristics of goldenberry fruit grown in Lam Dong Viet Nam were analysed. The mass of goldenberry fruit (American Southern variety) grown in Don Duong was larger but the volume was smaller than that planted in Lam Ha, so the fruit's density was higher. Besides, fruits are grown in Don Duong also showed a higher firmness value than those grown in Lam $\mathrm{Ha}$ and darker colour. There is no significant difference in other physical parameters of fruit grown in two locations of Lam Dong, Vietnam. According to chemical analyses from this study, it was observed that golden berries contain low energy but the high amount of antioxidants (vitamin C, A, total phenolic compounds), minerals and fibre. The goldenberries fruit grown in Lam Ha has a high acid and moisture content than the fruit grown in Don Duong. The biological compounds content of fruits grown in two locations were almost the same. Changes in fruit quality during storage are also carefully evaluated. According to the evaluation of these results, it was observed that the American Southern variety goldenberry was determined as featured types as a good new cultivar. Goldenberry fruit is a good source of bioactive compounds and its use as a functional food deserves further study. They also can be grown in large areas in Viet Nam in the future to ensure the needs of this functional food. 


\section{References}

Akbolat, D., Ertekin, C., Menges, H.O., Ekinci, K. and Erdal, I. (2008). Physical and nutritional properties of jujube (Zizyphus jujuba Mill.) growing in Turkey. Asian Journal of Chemistry, 20(1), 757-766

AOAC. (2005). Association of Official Analytical Chemist. Official Methods of Analysis. $18^{\text {th }}$ ed. Washington D.C., USA: AOAC.

Arunkumar, D., Avinash, N.G., Rao, H., Robin, K.B. and Samshuddin, S. (2015). Estimation of calcium, potassium and sodium contents in commonly consumed food of Karnataka coastal belt region, India. Pelagia Research Library. Der Chemica Sinica, 6(4), 100-103

Bernalte, M. J., Sabio, E., Hernandez, M.T. and Gervasini, C. (2003). Influence of storage delay on quality of 'Van'sweet cherry. Postharvest Biology and Technology, 28(2), 303-312. https:// doi.org/10.1016/S0925-5214(02)00194-1

Bravo, K., Sepulveda-Ortega, S., Lara-Guzman, O., Navas-Arboleda, A.A. and Osorio, E. (2015). Influence of cultivar and ripening time on bioactive compounds and antioxidant properties in Cape gooseberry (Physalis peruviana L.). Journal of the Science of Food and Agriculture, 95(7), 1562-1569. https://doi.org/10.1002/jsfa.6866

Carrasco, R.D. and Zelada, C.R. (2008). Determinación de la capacidad antioxidante y compuestos bioactivos de frutas nativas peruanas. Revista de la sociedad química del Perú, 74(2), 108-124. [In Spanish].

Celik, A., Ercisli, S. and Turgut, N. (2007). Some physical, pomological and nutritional properties of kiwifruit cv. Hayward. International Journal of Food Sciences and Nutrition, 58(6), 411-418. https:// doi.org/10.1080/09637480701252518

Dubois, M., Gilles, K.A., Hamilton, J.K., Rebers, P.A. and Smith, F. (1956). Colourimetric method for the determination of sugars and related substances. Analytical Chemistry, 28, 350 - 356. https:// doi.org/10.1021/ac60111a017

Ersoy, N. and Bagci, Y. (2011). Some Physico-chemical properties and antioxidant activities of goldenberry (Physalis peruviana L.), pepino (Solanum muricatum ait.) and passiflora (Passiflora edulis sims) tropical fruits. Selcuk Journal of Agriculture and Food Sciences, 25(3), 67-72.

Etzbach, L., Pfeiffer, A., Weber, F. and Schieber, A. (2017). Characterization of carotenoid profiles in goldenberry (Physalis peruviana L.) fruits at various ripening stages and in different plant tissues by HPLC-DAD-APCI-MS ${ }^{\mathrm{n}}$. Food Chemistry, 245, 508-
517. https://doi.org/10.1016/j.foodchem.2017.10.120

Fikselová, M., Šilhár, S., Mareček, J. and Frančáková, H. (2008). Extraction of carrot (Daucus carota L.) carotenes under different conditions. Czech Journal of Food Sciences, 26(4), 268-274. https:// doi.org/10.17221/9/2008-CJFS

Hakkinen, S.H., Kärenlampi, S.O., Heinonen, I.M., Mykkänen, H.M. and Törrönen, A.R. (1999). Content of the flavonols quercetin, myricetin, and kaempferol in 25 edible berries. Journal of Agricultural and Food Chemistry, 47(6), 2274-2279. https://doi.org/10.1021/j99811065

McCseady, R.M. (1971). Determination of starch and dextrin in methods of Food Analysis. $2^{\text {nd }}$ ed. A series of monographs. London, UK: Academic Press.

Mohsenin, N.N. (1986). Physical properties of plant and animals materials. $2^{\text {nd }}$ ed., p. 891. New York, USA: Gordon and Breach Science Publishers.

Morton, J.F. (1987). Cape gooseberry, Physalis peruviana L. In Fruits of Warm Climates. Miami, Florida: Purdue University, Center for New Crops and Plant Products.

National Research Council (NRC) (1989). Goldenberry (Cape Gooseberry). Lost crops of the incas: Littleknown plants of the andes with promise for worldwide cultivation., p. 240-251. Washington D.C., USA: National Academy Press.

Nawirska-Olszańska, A., Stępień, B., Biesiada, A., Kolniak-Ostek, J. and Oziembłowski, M. (2017). Rheological, chemical and physical characteristics of Golden Berry (Physalis peruviana L.) after convective and microwave drying. Foods, 6(8), 60. https://doi.org/10.3390/foods6080060

Olssen, M.E., Andersson, C.S., Oredsson, S., Berglund, R.H. and Gustavsson, K.E. (2006). Antioxidant levels and inhibition of cancer cell proliferation in vitro by extracts from organically and conventionally cultivated strawberries. Journal of Agricultural and Food Chemistry, 54(4), 1248-1255. https:// doi.org/10.1021/jf0524776

Ombwara, F.K., Wamocho, L.S. and Mugai, E.N. (2004). The Effect of Nutrient Solution of golStrength and Mycorrhizal Inoculation on Anthesis in Physalis peruviana presented at Proceedings of the 4th workshop on sustainable horticultural production in the tropics, 24- 27 November, p. 117-122. Eldoret, Kenya: Moi University.

Osorio, D. and Roldan, J. (2003). Volvamos al campo: manual de la uchuva. Bogotá, Colombia: Grupo Latino LTDA.

Ozdemir, Y., Ozturk, A. and Tüfekçi, S. (2016). Effect of two dipping pretreatments on drying kinetics of 
goldenberry (Physalis peruviana L.). African Journal of Agricultural Research, 11(1), 40-47. https://doi.org/10.5897/AJAR2014.8937

Ozturk, A., Özdemir, Y., Albayrak, B., Simşek, M. and Yildirim, K.C. (2017). Some nutrient characteristics of goldenberry (Physalis peruviana L.) cultivar candidate from Turkey. Scientific Papers. Series B, Horticulture. Vol. LXI, 2017 Print ISSN 2285-5653, CD-ROM ISSN 2285-5661, Online ISSN 22861580, ISSN-L 2285-5653.

Panda, H. (2013). The Complete Book on Fruits, Vegetables and Food Processing. Publisher: NIIR Project Consultancy Services Publisher.

Puente, L.A., Pinto-Muñoz, C.A., Castro, E.S. and Cortés, M. (2011) Physalis peruviana Linnaeus, the multiple properties of a highly functional fruit: a review. Food Research International, 44(7), 17331740. https://doi.org/10.1016/j.foodres.2010.09.034

Ramadan, M.F. (2011). Bioactive phytochemicals, nutritional value, and functional properties of cape gooseberry (Physalis peruviana): An overview. Food Research International, 44(7), 1830-1836. https:// doi.org/10.1016/j.foodres.2010.12.042

Rodrigues, E., Rockenbach, I.I., Cataneo, C., Gonzaga, L., Chaves, E.S. and Fett, R. (2009). Minerals and essential fatty acids of the exotic fruit Physalis peruviana L. Food Science and Technology, 29(3), 642-645. https://doi.org/10.1590/S010120612009000300029

Sharoba, A.M. and Ramadan, M.F. (2011). Rheological behaviour and physicochemical characteristics of goldenberry (Physalis peruviana) juice as affected by enzymatic treatment. Journal of Food Processing and Preservation, 35(2), 201-219. https:// doi.org/10.1111/j.1745-4549.2009.00471.x

Thompson, J. and Manore, M. (2017). Nutrition: An applied approach. $5^{\text {th }}$ ed. New York: Pearson.

Tran, B.L., Ton, N.M.N. and Dinh, T.N.T. (2004). Food biochemical experiment., p. 83. Ho Chi Minh, Vietnam: Ho Chi Minh City National University Publishing.

Trinchero, G.D., Sozzi, G.O., Cerri, A.M., Vilella, F. and Fraschina, A.A. (1999). Ripening-related changes in ethylene production, respiration rate and cell-wall enzyme activity in goldenberry (Physalis peruviana L.), a solanaceous species. Postharvest Biology and Technology, 16(2), 139-145. https://doi.org/10.1016/ S0925-5214(99)00011-3

Valdenegro, M., Fuentes, L., Herrera, R. and MoyaLeón, M.A. (2012). Changes in antioxidant capacity during development and ripening of goldenberry (Physalis peruviana L.) fruit and in response to 1- methylcyclopropene treatment. Postharvest Biology and Technology, 67, 110-117. https:// doi.org/10.1016/j.postharvbio.2011.12.021

Vasquez-Parra, J.E., Ochoa-Martínez, C.I. and BustosParra, M. (2013). Effect of chemical and physical pretreatments on the convective drying of cape gooseberry fruits (Physalis peruviana). Journal of Food Engineering, 119(3), 648-654. https:// doi.org/10.1016/j.jfoodeng.2013.06.037

Yıldız, G., İzli, N., Ünal, H. and Uylaşer, V. (2015). Physical and chemical characteristics of goldenberry fruit (Physalis peruviana L.). Journal of Food Science and Technology, 52(4), 2320-2327. https:// doi.org/10.1007/s13197-014-1280-3 